\title{
PLASMA LEVELS OF ANTIDIURETIC HORMONE IN MAN DURING HALOTHANE ANAESTHESIA AND SURGERY
}

\author{
Tsutomu Oyama, M.D., K. Sato, M.D. and K. Kimura, M.D. *
}

ANAESTHESIA AND SURGERY are known to produce oliguria in man. The antidiuresis is influenced by solute load, alteration in renal function, and a release of antidiuretic hormone (ADH) of the posterior pituitary gland. Although Deutsch et al. ${ }^{1}$ have suggested that halothane anaesthesia in man might increase ADH secretion, direct measurement of ADH levels in human plasma during anaesthesia have not been reported previously. However, Philbin et al. ${ }^{2}$ recently observed that halothane anaesthesia failed to elevate plasma ADH levels significantly in dogs. Recently we clearly demonstrated a remarkable participation of $\mathrm{ADH}$ in decreased urine output and in elevation of urine osmolality in patients anaesthetized with ether ${ }^{3}$ and methoxyflurane. ${ }^{4}$

The present study was undertaken to investigate the effects of halothane anaesthesia alone on the plasma ADH concentrations of patients, and to compare the results with the effects of anaesthesia plus surgery. The authors attempted to explore the quantitative relationship between plasma ADH levels and the urine volume, urine osmolality and blood osmolality, in order to evaluate the role of ADH in the antidiuresis produced by halothane.

\section{Material AND METhOD}

Fourteen patients, ranging in age from 21 to 61 years, were the subjects of the study. All underwent elective operations, and none had renal, hepatic, or endocrine disease. They underwent laparotomy except for three patients who underwent orthopaedic surgery (Table I). All patients were fasted and no water was allowed for about 10 hours prior to induction of anaesthesia. Five per cent fructose 1.4 to $2.0 \mathrm{ml} / \mathrm{min}$ was infused from 1 hour before induction of anaesthesia until the end of operation. In addition, blood was transfused to replace the loss due to sampling and operation.

Each patient was premedicated with pentobarbitone $100 \mathrm{mg}$ orally $1 \frac{1}{2}$ hours prior to the induction of anaesthesia, followed by atropine $0.5 \mathrm{mg}$ and pethidine $35 \mathrm{mg}$ intramuscularly 1 hour before the induction of anaesthesia. Halothane anaesthesia was induced with inspired concentration between 1.0 and 2.0 per cent by Fluotec Mark II vaporizer, combined with $\mathrm{N}_{2} \mathrm{O}(2 \mathrm{~L} / \mathrm{min})$ and $\mathrm{O}_{2}(2 \mathrm{~L} / \mathrm{min})$ under a mask, at 8:30 am. After endotracheal intubation carried out under suxamethonium $40 \mathrm{mg}$, anaesthesia was maintained with halothane, $\mathrm{N}_{2} \mathrm{O}(2 \mathrm{~L} / \mathrm{min})$ and $\mathrm{O}_{2}(2 \mathrm{~L} / \mathrm{min})$. Tubocurarine 15 to $30 \mathrm{mg}$ in divided doses was injected during intraabdominal operation when needed. Japan.

"Department of Anaesthesia, Hirosaki University School of Medicine, Hirosaki, Aomori-Ken, 
TABI.E I

Patients Studien and Operation Performed

\begin{tabular}{rrrrl}
\hline \hline Cases & Patients & Age & Sex & \multicolumn{1}{c}{ Surgery performed } \\
\hline 1 & K.N. & 24 & M & Subtotal gastrectomy \\
2 & C.N. & 56 & F & Simple hysterectomy \\
3 & T.T. & 42 & M & Exploratory thoracotomy \\
4 & S.I. & 27 & M & Skin graft \\
5 & N.I. & 61 & F & Formation of artificial anus \\
6 & F.O. & 42 & F & Sigmoidectomy \\
7 & C.K. & 36 & F & Panhysterectomy \\
8 & S.S. & 32 & M & Subtotal gastrectomy \\
9 & K.S. & 28 & M & Subtotal gastrectomy \\
10 & J.N. & 58 & M & Reconstruction of esophagus \\
11 & K.M. & 22 & F & Simple hysterectomy \\
12 & S.H. & 38 & M & Subtotal gastrectomy \\
13 & I.N. & 26 & F & Simple hysterctomy \\
14 & K.E. & 21 & F & Extirpation of bone tumor \\
\hline
\end{tabular}

Ventilation was controlled or assisted intermittently throughout the procedure. A moderate depth of anaesthesia was maintained by clinical judgment. In addition occasional observation by Fes and gas chromatographic analysis of arterial halothane concentration were made by Oyama's method, ${ }^{7}$ using helium as a carrier gas and Molecular Shieve 5-A as a column packing agent. The details of the method of administration of halothane was as has been described previously. ${ }^{13}$ Anaesthesia alone lasted for at least $1_{12}^{1 / 2}$ hours in each case. $\mathrm{PO}_{2}, \mathrm{PCO}_{2}$, and $\mathrm{pH}$ were determined in arterial blood at $37^{\circ} \mathrm{C}$ by means of Astrup ultramicro equipment and a Severinghaus electrode.

Five blood samples were obtained from each patient; in the morning just before induction of anaesthesia, 30 minutes, one hour, and 1/2 hours after induction of anaesthesia before surgery, and 10 minutes after the start of surgery. Thirty $\mathrm{ml}$ samples of venous blood were drawn, the serum was separated within 30 minutes, and the urine was collected through an indwelling catheter. The determinations of plasma ADH levels and urine osmolality were made by the previously described method., ${ }^{5,6}$ Blood volume was measured in 5 patients by means of volemetron ${ }^{8}$ in the pre-induction period and at one hour after anaesthesia alone, but before surgery.

\section{Results}

The preoperative mean plasma ADH level was $2.8 \mu \mathrm{v} / \mathrm{ml}$. The plasma ADH level was elevated to $5.0 \mu \mathrm{v} / \mathrm{ml}$ after 30 minutes of halothane anaesthesia alone. After one hour of anaesthesia it significantly increased to $6.8 \mu \mathrm{U} / \mathrm{ml}(p<0.001)$; at $\mathrm{l}^{1 / 2}$ hours it was $7.6 \mu \mathrm{v} / \mathrm{ml}$. The plasma ADH concentration increased markedly to $20.9 \mu \mathrm{U} / \mathrm{ml}(p<0.0001) 10$ minutes after the start of operation as shown in Table II.

Urine volume was $1.1 \mathrm{ml} / \mathrm{min} 30$ minutes from the start of infusion of 5 per cent fructose until immediately before induction of anaesthesia. It decreased to 0.4 $\mathrm{ml} / \mathrm{min}(p<0.02) 30$ minutes after induction; in the next 30 minutes the value was $0.5 \mathrm{ml} / \mathrm{min}(p<0.005)$; it gradually and significantly decreased later on as shown in Table III. Urine osmolality reached the highest level from the control value of 373 milliosmol (mOsm) / $\mathrm{L}$ to $449 \mathrm{mOsm} / \mathrm{L}$ at $1 \frac{1}{2}$ hours after the start of 
TABLE II

Plasma adh Levels $\left(\mu \mathrm{U} / \mathrm{ML}\right.$ ) During Halothane- $\mathrm{N}_{2} \mathrm{O}$ ANAESTHESIA AND SURGERY

\begin{tabular}{cccccc}
\hline \multicolumn{5}{c}{} & \multicolumn{5}{c}{ Time in minutes } \\
\cline { 2 - 6 } Cases & Pre- & Anaes. & & Op. \\
\hline 1 & ind. & 30 & 60 & 90 & 10 \\
\hline 2 & 8.8 & 2.5 & 8.4 & 6.7 & 53.3 \\
3 & 2.9 & 13.6 & 12.3 & 21.8 & 15.0 \\
4 & 4.3 & 5.7 & 7.6 & 5.1 & 2.7 \\
5 & 4.0 & 9.1 & 14.0 & 7.5 & 18.0 \\
6 & 1.5 & 2.0 & 1.4 & 4.5 & 17.5 \\
7 & 2.3 & 1.0 & 3.0 & 4.5 & 8.8 \\
8 & 1.0 & 3.6 & 5.0 & -5 & 26.0 \\
9 & 2.0 & 5.0 & 10.8 & 9.4 & 20.0 \\
10 & 2.9 & $\mathbf{3 . 7}$ & 7.4 & 7.1 & 26.5 \\
11 & 3.5 & 6.9 & 8.2 & 9.9 & 16.1 \\
12 & 0.8 & 2.1 & 3.1 & 4.1 & 13.1 \\
13 & 2.5 & 8.4 & 5.5 & $\mathbf{9 . 5}$ & 27.3 \\
14 & 1.2 & 2.8 & 3.6 & 3.2 & 21.2 \\
Mean & 2.1 & 3.5 & 4.2 & 6.0 & 16.8 \\
SE & 2.8 & 5.0 & 6.8 & 7.6 & 20.9 \\
$p$ & 0.52 & 0.90 & 0.97 & 1.27 & 3.18 \\
\hline
\end{tabular}

TABLE III

Changes in Urine Osmolatity and Urine Output during Halothane- ${ }_{2} \mathrm{O}$ Anaesthesia IN MAN

\begin{tabular}{lrrrrrr}
\hline \hline & & \multicolumn{5}{c}{ Time in minutes } \\
\cline { 3 - 7 } & & Pre-ind. & Anaes. 30 & \multicolumn{1}{c}{60} & 90 & Op. 10 \\
\hline Urine & Mean & 373 & 366 & 415 & 449 & 480 \\
Osmolality (mOsm/L) & SE & \pm 52 & \pm 45 & \pm 59 & \pm 61 & \pm 62 \\
Urine & Mean & 1.14 & 0.47 & 0.57 & 0.27 & 0.27 \\
Output (ml/min) & $\mathrm{SE}$ & \pm 0.22 & \pm 0.05 & \pm 0.13 & \pm 0.05 & \pm 0.05 \\
Plasma & Mean & 291 & 292 & 294 & 293 & 293 \\
Osmolality (mOsm/L) & $\mathrm{SE}$ & \pm 6 & \pm 5 & \pm 5 & \pm 6 & \pm 6 \\
\hline
\end{tabular}

TABLE IV

Arterial Blood Gas Measurement during Halothane Anaesthesia

\begin{tabular}{|c|c|c|c|c|c|c|}
\hline & & \multicolumn{5}{|c|}{ Time in minutes } \\
\hline & & Pre-ind. & Anaes. 30 & 60 & 90 & Op. 10 \\
\hline $\mathrm{pH}$ & $\underset{\text { SE }}{\text { Mean }}$ & $\begin{array}{r}7.39 \\
\pm 0.01\end{array}$ & $\begin{array}{r}7.34 \\
\pm 0.02\end{array}$ & $\begin{array}{r}7.35 \\
\pm 0.01\end{array}$ & $\begin{array}{r}7.36 \\
\pm 0.02\end{array}$ & $\begin{array}{r}7.32 \\
\pm 0.02\end{array}$ \\
\hline $\mathrm{PCO}_{2}(\mathrm{~mm} \mathrm{Hg})$ & Mean & 36.7 & 31.5 & 32.1 & 32.7 & 31.9 \\
\hline $\mathrm{Po}_{2}(\mathrm{~mm} \mathrm{Hg})$ & $\begin{array}{l}\text { SE } \\
\text { Mean }\end{array}$ & $\begin{array}{l} \pm 1.3 \\
84.2\end{array}$ & $\begin{array}{l} \pm 1.6 \\
208.3\end{array}$ & $\begin{array}{l} \pm 1.5 \\
211.4\end{array}$ & $\begin{array}{l} \pm 1.7 \\
206.1\end{array}$ & $\begin{array}{l} \pm 1.6 \\
210.5\end{array}$ \\
\hline & $\mathrm{SE}$ & \pm 2.3 & \pm 9.1 & \pm 10.6 & \pm 12.7 & \pm 13.8 \\
\hline $\mathbf{B E}(\mathrm{mEq} / \mathrm{L})$ & Mean & 1.3 & 0.8 & 0.2 & -0.3 & -0.5 \\
\hline $\mathrm{HCO}_{3}(\mathrm{mEq} / \mathrm{L})$ & $\begin{array}{c}\text { SE } \\
\text { Mean }\end{array}$ & $\begin{array}{r} \pm 0.4 \\
25.3\end{array}$ & $\begin{array}{l} \pm 1.2 \\
25.6\end{array}$ & $\begin{array}{r} \pm 1.0 \\
24.7\end{array}$ & $\begin{array}{l} \pm 1.1 \\
23.9\end{array}$ & $\begin{array}{l} \pm 0.9 \\
22.3\end{array}$ \\
\hline \multicolumn{2}{|c|}{$\begin{array}{l}\text { Halothane concentration, } \mathrm{mg} / 100 \mathrm{ml} \\
\quad \pm=\mathrm{SD}\end{array}$} & \pm 0.8 & $\begin{array}{r} \pm 1.3 \\
9.7 \\
\pm 0.8\end{array}$ & $\begin{array}{r} \pm 1.2 \\
14.2 \\
\pm 1.1\end{array}$ & $\begin{array}{r} \pm 1.1 \\
13.8 \\
\pm 1.3\end{array}$ & $\begin{array}{r} \pm 1.0 \\
14.5 \\
\pm 1.6\end{array}$ \\
\hline
\end{tabular}




\section{Plasma ADH Levels, Serum and Urine Osmolality, and Urine Output during Halothane- $\mathrm{N}_{2} \mathrm{O}$ Anesthesia}

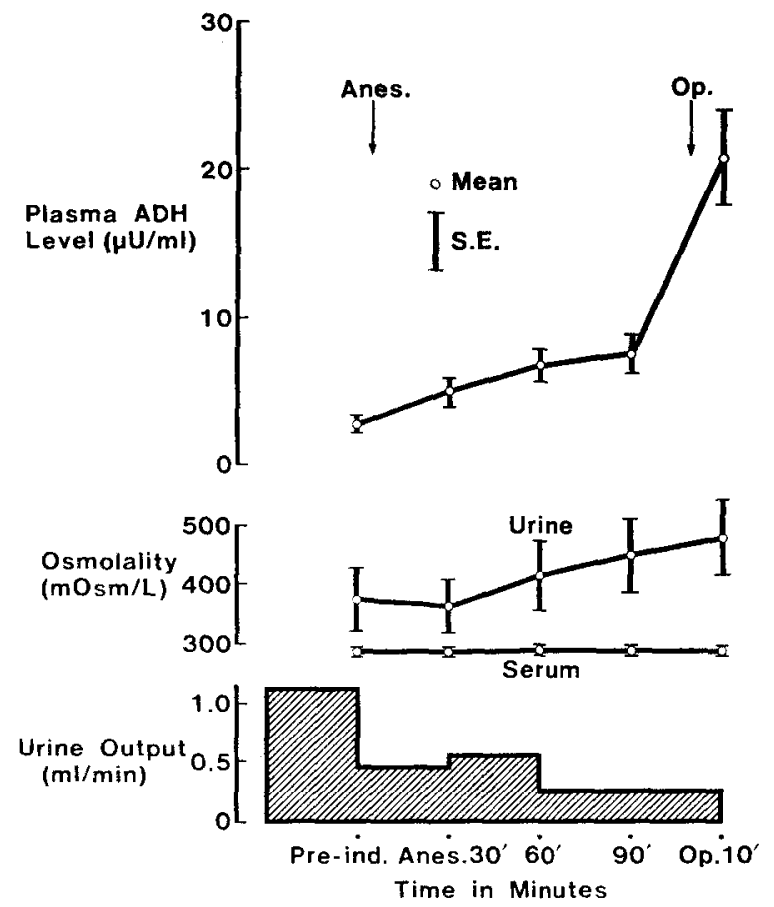

Frouke 1. Plasma ADH levels increased significantly during halothane anaesthesia alone and surgery. Despite of the costant serum osmolality, urine osmolality was elevated and urine output was decreased during the procedure.

anaesthesia, followed by a gradual increase to $480 \mathrm{mOsm} / \mathrm{L}$ during the operation. Serum osmolality showed little variation from the control pre-induction value of $291 \mathrm{mOsm} / \mathrm{L}$ throughout the procedure (Table III). Measurement of arterial blood gases demonstrated that neither anoxia nor metabolic acidosis existed during the course of the procedure ( Table IV). The mean pre-operative circulating total blood volume in 5 patients was $3,760 \mathrm{ml}(3,200 \sim 4,100)$. It increased to $4,020 \mathrm{ml}(3,500 \sim$ $4,500)$ one hour after the induction of anaesthesia.

\section{Discussion}

Since the preoperative mean plasma ADH level was within the normal range $(0.4-3.5 \mu \mathrm{U} / \mathrm{ml})$, the effects of preanaesthetic medication on plasma ADH were undetectable under the condition of our study.

The plasma ADH level at pre-induction in a patient (No. 1) who complained of severe anxiety was very high $(8.8 \mu \mathrm{v} / \mathrm{ml})$ suggesting the influence of emotional stress on ADH secretion, and it implied the significance of premedication on plasma 
ADH level. Papper et al. ${ }^{9}$ used pethidine $100 \sim 185 \mathrm{mg}$ in 16 patients and secobarbital $200 \mathrm{mg}$ in 10 patients and found urine volume decreased by these drugs ( 23 per cent and 14 per cent respectively), but urine osmolality did not increase. Therefore, they speculated that pethidine and barbiturate do not stimulate ADH secretion. Our present study appears to support their speculation.

The plasma ADH level was increased significantly to about 2.4 times the preinduction level after one hour of halothane anaesthesia alone. This is in contrast with the statement of Philibin et al. ${ }^{2}$ who recently reported that they failed to find any significant effect of halothane (0.4-0.5 per cent) on the plasma ADH levels in the dog. In our study the magnitude of increase in plasma ADH level by halothane was almost 13 of that caused by ether anaesthesia in man, ${ }^{3}$ but it was almost similar to the degree of elevation by methoxyflurane anaesthesia. ${ }^{4}$ The plasma ADr level rose further markedly after the start of operation, similar to the magnitude of elevation found by us under ether anaesthesia. ${ }^{3}$ Decrease in urinary output and increase in urine osmolality correlated with the elevation of plasma ADI levels both during halothane anaesthesia alone and during operation. However, there was little variation in serum osmolality $(291 \mathrm{mOsm} / \mathrm{L})$. This phenomenon of constant serum osmolality accords well with the observation by Deutsch et al. ${ }^{1}$ Despite infusion of 4 per cent fructose $1,000 \mathrm{ml}$ within $30-40$ minutes in man, they found constant serum osmolality ranging from 285 to $287 \mathrm{mOsm} / \mathrm{L}$.

It is well known that halothane anaesthesia significantly diminishes renal plasma flow, glomerular filtration, and water and electrolyte excretion. Deutsch $e t$ al., ${ }^{1}$ who gave halothane anaesthesia alone for 165-236 minutes in 3 volunteers, found that despite the constant serum osmolality $(279-285 \mathrm{mOsm} / \mathrm{L})$, urine osmolality increased markedly to as much as 5 times in comparison with pre-induction control value (from 89 to $442 \mathrm{mOsm} / \mathrm{L}$ ). In addition alcohol, which depresses $\mathrm{ADH}$ secretion, blocked the elevation of urine osmolality in their experiments. They speculated that halothane anaesthesia caused the secretion of ADH. Our present study clearly demonstrates that the elevated plasma ADH level plays an important role in the oliguria and elevation of urinary osmolality during halothane anaesthesia and surgery.

The primary physiological functions of the posterior pituitary ADH (vasopressin) are the regulation of the osmotic pressure of extracellular fluid and the regulation of blood volume. It stimulates tubular reabsorption of free water, concentrating urine, and decreases urine volume; it also constricts blood vessels. The plasma ADH level is influenced by many factors such as secretion of ADH from the posterior pituitary, metabolism in the liver and kidneys, and renal excretion. ${ }^{10}$

There are many factors which are considered to affect the ADH secretion from the pituitary glands and thereby control the tonicity and volume of the body fluids. ${ }^{10}$ They include stimulation of osmoreceptors located in the supraoptic and paraventricular nuclei of the hypothalamus, which are sensitive to changes in the effective solute concentration of the extracellular fluids, stimulation of baroreceptors in the cartoid sinus or aortic arch by arterial hypotension, and stimulation of left atrial volume receptors by decreases in blood volume.

The effect of halothane anaesthesia on ADH secretion is speculated to be due to the direct stimulation on the hypothalamo-pituitary system for the following 
wasons. Although Aubry and his co-workers ${ }^{11}$ reported that an increase of 2 per cent in the osmotic pressure of the plasma is sufficient to inhibit a water diuresis in man, the increase in blood osmolality during halothane anaesthesia was too little to be attributable to the increase in blood ADH. According to Share, ${ }^{10}$ when extracellular fluid volume was reduced by 15 per cent (a 9 per cent reduction in blood volume), there was a sixfold increase in the blood level of vasopressin, although mean arterial blood pressure was unchanged. But we found increase instead of decrease in blood volume during halothane anaesthesia. The anaesthetic depth, changes in body temperature, or changes in blood pressure might account in part for the variations in plasma ADH levels. However, these factors were kept as constant as possible during the procedure. It is difficult to postulate a clear cut mechanism of elevation of the plasma ADH level and its relation to biotransformation and excretion during halothane anaesthesia in the present study. However, our data are interpreted as indicating that the raised ADH secretion during anaesthesia and surgery contribute in part to the effect of decreased urine formation. Furthermore, it was quite appartnt that plasma ADH changed rapidly during anaesthesia and surgery.

We observed a transient and marked elevation in the plasma ADH level associated with peritoneal incision or visceral traction, which agrees with the finding of Moran and co-workers. ${ }^{12}$ According to them a gradual decline of ADH to normal values after closing of the skin incision is usually observed by the fifth postoperative day, following major surgical procedures.

The clinical application of our study is as follows: (1) the sedation by premedication is of importance to allay apprehension and depress the elevation of plasma ADH level. (2) The importance of administration of adequate fluid before induction and during induction of anaesthesia. It is recommended to infuse at least 200 to $300 \mathrm{mI}$ of 5 per cent glucose or dextrose in distilled water for adult patients before and during induction of anaesthesia to maintain fluid balance and depress ADH secretion. The patient who has had no fluid intake for 12 or more hours before arriving in the theatre, is in a state of dehydration, slight ADH activity and concentrated urine. The preoperative mild or severe dehydration will further enhance the intraoperative and postoperative oliguria or anuria. (3) For hypophysectomy, it is not infrequent for us to encounter diabetis inspidus in the preoperative or postoperative period. Therefore, anaesthetics such as ether, halothane and methoxyflurane which cause ADI secretion will be those of choice.

\section{SumMaky and CONCluSion}

Effects of halothane-nitrous oxide and oxygen anaesthesia alone for $1^{1 / 2}$ hours and of surgery on plasma ADH, serum osmolality, urine volume and urine osmolality were studied in 14 patients. The mean plasma ADH level after premedication with pentobarbitone, pethidine and atropine was $2.8 \mu \mathrm{v} / \mathrm{ml}$, which was within normal limits $(0.4-3.5 \mu \mathrm{v} / \mathrm{ml})$. It increased significantly by as much as 2.7 times the control level after $1^{1 / 2}$ hours of halothane anaesthesia. Surgical stress further increased it (7.5 times). Serum osmolality remained relatively stable. ADH secretion appears to play a role on the decreased urine volume and elevated urine osmolality. The clinical application of the present study is also discussed. 


\section{RÉSUMÉ}

Nous avons étudié chez 14 malades anesthésiés à l'halothane, protoxyde d'azote et oxygène, les effets de l'anesthésie seule durant une heure et demie et les effets de la chirurgie sur le taux d'ADH dans le plasma, sur l'osmolalité sérique, sur le volume urinaire, sur l'osmolalité de l'urine. Après la prémédication avec du pentobarbitone, de la pethidine et de l'atropine, le taux moyen d'ADH dans le plasma était de $2.8 \mu \mathrm{u} / \mathrm{ml}$, ce qui se range dans les limites de la normale $(0.4-3.5 \mu \mathrm{v} / \mathrm{ml})$. Après une heure et demie d'anesthésic à l'halothane, le taux a augmenté de 2.1 fois. L'agression chirurgicale a provoqué une élévation additionnelle (7.5 fois). L'osmolalité sérique est demeurée relativement stable. La sécrétion d'ADH semble être un facteur participant à la diminution du volume d'urine et à l'élévation de l'osmolalité de l'urine. Nous avons également discuté l'application clinique de cette étude.

\section{REFERENCES}

1. Deutsch, S.; Goldberg, M.; Stephen, G. M.; \& WU, W. Effects of Halothane Anesthesia on Renal Function in Normal Man. Anesthesiology, 27: 793 ( 1966 ).

2. Pfinbin, D. M.; Baratz, R. A.; \& Patrenson, R. W. The Effect of Carbon Dioxide on Plasma Antidiuretic Hormone Levels during Intermittent Positivepressure Breathing. Anesthesiology, 33: 345 (1970).

3. Oyama, T. \& Kimura, K. Plasma Levels of Antidiuretic Hormone in Man during Diethyl Ether Anaesthesia and Surgery. Canad. Anaesth. Soc. J., 17: 495 (1970).

4. Oyama, T. \& Sato, $K$. Plasma Levels of Antidiuretic Hormone in Man during Methoxyflurane Anaesthesia and Surgery. Anaesthesia, 25: 500 (1970).

5. Weinstein, H. R.; Berne, R. M.; \& SAchs, H. Vasopressin in Blood: Effect of Haemorrhage. Endocrinology, 66: 712 (1960).

6. Share, L. Acute Reduction in Extra Cellular Volume and the Concentration of Antidiuretic Hormone in Blood. Endocrinology, 69: 925 (1961).

7. Oyama, T.; Matsumoto, F.; Sato, K.; \& Kamada, M. Gas Chromatographic Determinations of Various Gases - Fluothane, Nitrous Oxide, $\mathrm{CO}_{2}$ and $\mathrm{O}_{2}$. Jap. J. Anesth., 17: 773 (1968).

8. Free, A. H. Automated Blood Volume, Plasma Volume, and Red Cell Volume Measurements. Amer. J. Clin. Path., 53: 688 (1970).

9. Papper, S.; Belsky, J. L.; Bleifer, K. H.; Saxon, L.; \& Smtrh, W. P. Effect of Meperidine and Secobarbital Upon Renal Excretion of Water and Solute in Man. J. Lab. \& Clin. Med., 56: 727 (1960).

10. Share, L. Vasopressin: Its Bioassay and the Physiological Control of its Release. Am. J. Med., 42: 701 (1967).

11. Aubry, R. H.; Nankin, H. R.; Moses, A. M.; \& Streeten, D. H. P. Measurement of the Osmotic Threshold for Vasopressin Release in Human Subjects and its Modification by Cortisol. J. Clin. Endocrinol., 25: 1481 (1965).

12. Moran, W. H.; Mrltenberger, F. W.; Shuayb, W. A.; \& Zimmermann, B. The Relationship of Antidiuretic Hormone Secretion to Surgical Stress. Surgery, 56: 99 ( 1964 ).

13. Oyama, T. \& Takiguchi, M. Plasma Levels of ACTH and Cortisol in Man during Halothane Anesthesia and Surgery. Anesth. \& Analg., 49: 363 (1970). 